\title{
Relacje Turcji z Unią Europejską. Kwestia członkostwa Republiki Cypru we Wspólnocie
}

\author{
Turkish Relations with the European Union. The issue \\ of Republic of Cyprus membership in the Community
}

\begin{abstract}
Streszczenie:
Kwestia cypryjska stanowi ważną część tureckiej koncepcji polityki zagranicznej jako element polityki mocarstwowej pozostały po upadku imperium Osmańskiego. Współcześnie wokół problemu cypryjskiego uaktywniły się zależności, które angażują poza Turcją Unię Europejską i Stany Zjednoczone, a także społeczność międzynarodową. Polityka wobec Cypru stanowi jedynie część relacji Ankary z Brukselą, obejmujących szerokie spektrum zależności gospodarczych, politycznych oraz bezpieczeństwa. Problem cypryjski ma charakter bezpośredniego czynnika w relacjach dwustronnych i określa dynamikę postępu w tureckich negocjacjach akcesyjnych, jest również przyczyną rozgrywek dyplomatycznych, które dowiodły istnienia zasadniczego problemu w relacjach pomiędzy Turcją i Unią Europejską. Kazus cypryjski wykazał istnienie realnych granic partnerskich stosunków pomiędzy muzułmańską, autorytarną Turcją oraz liberalną, chrześcijańską Europą.
\end{abstract}

Słowa kluczowe: Turcja, Unia Europejska, Cypr, polityka zagraniczna

\begin{abstract}
:
Cyprus issue is an important part of Turkish foreign policy concept as an element of imperial politics remain after the collapse of the Ottoman Empire. Today, the Cyprus problem engage Turkey, the European Union the United States and the global community. Policy towards Cyprus is only part of Ankara's relations with Brussels, which cover a wide range of economic, political and security issues. Cyprus problem is a direct factor in bilateral relations and determines the dynamics of progress in Turkey's accession negotiations, is also a cause of diplomatic strategy, which established
\end{abstract}


Michał Alagierski - Relacje Turcji z Unią...

the crucial problem in the relations between Turkey and the European Union. The case of Cyprus showed a real limits of partnership relations between Muslim, authoritarian Turkey and liberal, Christian Europe.

Key words: Turkey, European Union, Cyprus, international policy

\section{Wstęp}

Rozważania na temat stosunków zewnętrznych Turcji należy zacząć od zgłębienia podstaw, na których oparta została republika stworzona dzięki heroicznym dokonaniom Mustafy Kemala Atatürka oraz jego towarzyszy. Wypracowane wówczas fundamenty ustroju stoją u podstaw współczesnej doktryny tureckiego państwa. W polityce międzynarodowej działalność kolejnych rządów w Turcji opiera się na doktrynie nieangażowania się w globalne konflikty. Turcja od dziesięcioleci próbuje odbudować swoją pozycję, dążąc jednocześnie do wskrzeszenia idei mocarstwowych. Bez względu na zmiany wewnętrzne czyni to w sposób umiarkowany i wyważony. Pozornie taka postawa jest sprzeczna, jednak w rzeczywistości przyczynia się do osiągania dalekosiężnych celów, które ograniczają do minimum czynnik ryzyka.

Jednym z kluczowych elementów polityki zagranicznej Turcji jest utrzymanie wpływów na Cyprze. Wagę tego państwa determinuje strategiczne położenie, oddziałujące na całość polityki bezpieczeństwa Turcji. Problem cypryjski zyskał na znaczeniu wraz ze wzrostem zainteresowania międzynarodowego. Możliwość utraty tej strategicznie położonej wyspy wymusiła na Turcji konieczność wypracowania odpowiedniej polityki. Delikatny charakter dyplomatycznych rozgrywek, których celem jest przejęcie kontroli nad Cyprem, zyskiwał na znaczeniu pod wpływem aspiracji kolejnych graczy. Wraz z upływem czasu ranga Cypru urosła do ogromnych rozmiarów. Początkowo prawo do kontroli rościły sobie Grecja i Turcja, które w wyniku niepowodzenia prób zdominowania Cypru zaczęły realizować swoje cele w oparciu o instytucje międzynarodowe. $\mathrm{Z}$ czasem w rozgrywkę po- 
między Atenami i Ankarą włączyły się Stany Zjednoczone, Organizacja Narodów Zjednoczonych, a ostatnio także Unia Europejska.

\section{Relacje Turcji z Unią Europejską. Kwestia członkostwa Republiki Cypru we Wspólnocie}

Kwestia cypryjska stanowi ważny element relacji Turcji z Brukselą, służąc niejednokrotnie do wzajemnych rozgrywek. Godne zauważenia jest, iż działania takie mają dwuznaczny charakter. Przyjęcie Republiki Cypru do Unii stanowiło efekt żmudnych zabiegów dyplomatycznych, które były podejmowane przez obie strony. Ankara zdołała zachować trzeźwość osądu wydarzeń mimo nacisków. W konfrontacji z Brukselą, wspieraną przez Organizację Narodów Zjednoczonych, Turcja nie utraciła możliwości wpływania na sytuację na Cyprze.

Cypr jest największą wyspą we wschodniej części Morza Śródziemnego, usytuowaną na pograniczu wpływów kultury greckiej i orientalnej. Dzieje wyspy Afrodyty kształtowały powtarzające się podboje. Wpływ Bizancjum spowodował, że greccy mieszkańcy Cypru przyjęli prawosławie. W 1570 r. podbity przez armie osmańskie został poddany stopniowej kolonizacji tureckiej. Kres dominacja Osmanów nastąpił w 1878 r. wraz z przybyciem Brytyjczyków, którzy wykorzystywali wyspę jako bazę marynarki wojennej. Turecka ludność pozostająca pod wpływem islamu koegzystowała z prawosławną ludnością grecką. Niebawem na Cyprze zaczęły funkcjonować dwa ośrodki władzy, przyczyniając się do pogłębienia podziałów ${ }^{1}$.

Upadek systemu kolonialnego po drugiej wojnie światowej wpłynął na dążenia Cypryjczyków do uzyskania niepodległości. Kwestia cypryjska nabrała znaczenia w latach pięćdziesiątych za sprawą cypryjskiego arcybiskupa Makariosa. Prawosławny duchowny sprzyjał idei połączenia Cypru z Grecją. Możliwość powołania federacji grecko-

\footnotetext{
${ }^{1}$ B. Eryilmaz, „Europeanization of Turkish Foreign Policy: Cyprus Case”, referat zaprezentowany na konferencji Global and Regional Governance - European Perspectives and Beyond, Uniwersytet Wrocławski, 24-26 maja 2007, s. 26-28.
} 
Michał Alagierski - Relacje Turcji z Unią...

cypryjskiej została odrzucona przez Ateny pod wpływem nacisków brytyjskich ${ }^{2}$. Polityka prowadzona przez Londyn wzmogła działalność Narodowej Organizacji Bojowników Cypryjskich (EOKA), której oddziały dokonywały zamachów na brytyjską administrację kolonialną3.

Działalność EOKA, którą wsparła Grecja, stworzyła zagrożenie dla mniejszości tureckiej. Liderzy cypryjskich Turków zwrócili się o pomoc do Ankary, która zaczęła wywierać wpływ na Wielką Brytanię, domagając się rozpoczęcia negocjacji w sprawie niepodległości wyspy. W proces negocjacyjny włączyła się także Organizacja Narodów Zjednoczonych (ONZ) ${ }^{4}$. W lutym 1959 r. odbyły się konferencje w Londynie i Zurychu. Obecni na nich przedstawiciele Wielkiej Brytanii, Grecji, Turcji oraz przywódcy cypryjskich Greków i Turków postanowili powołać do życia Republikę Cypru. Sygnatariusze układu zobowiązali się stać na straży integralności terytorialnej wyspy oraz zgodzili się na powołanie odrębnych instytucji politycznych, które miały funkcjonować niezależnie od władz centralnych w Nikozji. Porozumienie zostało sformułowane w taki sposób, iż każde z trzech państw (Grecja, Turcja, Wielka Brytania) rezerwowało sobie prawo do samodzielnego działania w wypadku braku możliwości osiągnięcia powszechnego porozumienia ${ }^{5}$. Skutkiem przyjętych ustaleń było ogłoszenie w Londynie niepodległości Cypru 16 kwietnia 1960 r.6. Politolog z Uniwersytetu w Stambule Kıvanç Ulusoy, porównując układy zawarte w Londynie, dowodzi, że przypominały one rozwiązania wprowadzone po drugiej wojnie światowej w Berlinie, w którym cztery mocarstwa podzieliły między siebie kompetencje związane z władzą okupacyjną, nadając szeroki zakres władzy w zakresie administracji cywilnej Niemcom? ${ }^{7}$.

\footnotetext{
2 W. Mallinson, Cyprus: A Modern History, Londyn 2008, s. 116.

3 Ibidem, s. 117.

4 F. Canan, The Impact of Europeanization on Turkish Foreign Policy: An Analysis of Period Since 1999, Londyn 2009, s. 57.

${ }^{5}$ F. Canan, The Impact of Europeanization..., op. cit., s. 57.

6 Ibidem.

${ }^{7}$ K. Ulusoy, Europeanization Time Constraint: The Cyprus Case, [w:] B. Akçay, B. Yilmaz (red.), Turkey's Accession to the European Union: political and Economic Challenges, Lexington Books, Nowy Jork 2013, s. 281.
} 
Rezygnacja Brytyjczyków z pełnej kontroli nad Cyprem umożliwiła Grecji i Turcji walkę o ustanowienie własnej strefy wpływów ${ }^{8}$.

W 1963 r., gdy prezydent Makarios zainicjował rozmowy z lewicowym rządem w Grecji kierowanym przez Andreasa Papandreu, doszło do eskalacji nastrojów społecznych na Cyprze. Turecka społeczność obawiała się realizacji planu utworzenia państwa greko-cypryjskiego9. Aktywność dyplomacji greckiej zaniepokoiła Ankarę, która rozważała wysłanie wojska ${ }^{10}$. Zdaniem politologa Heinza Kramera udało się uniknąć wojny dzięki interwencji sojuszników z NATO. Autor podkreśla, że zwłaszcza dyplomacja Stanów Zjednoczonych odegrała decydującą rolę w niedopuszczeniu do konfrontacji zbrojnej ${ }^{11}$. Prezydent Lyndon Johnson zaproponował wysłanie na Cypr sił pokojowych ONZ. W marcu 1964 r. Rada Bezpieczeństwa wydała w tej sprawie rezolucję. Po fiasku pierwszej propozycji Stany Zjednoczone upoważniły sekretarza stanu Deana Achesona do rozmów na temat planu zjednoczenia Cypru z Grecją. W zamian za zrzeczenie się wpływów na wyspie Turcja miała otrzymać od Aten jedną z wysp na Morzu Egejskim oraz bazę marynarki wojennej na Cyprze ${ }^{12}$. Porozumienie nie doszło do skutku, ponieważ obie strony liczyły na uzyskanie pełnej kontroli nad Cyprem ${ }^{13}$. Dyplomacja amerykańska w latach 1963-1967 czyniła starania, aby zapobiec wojnie, zagrażającej stosunkom wewnątrz NATO ${ }^{14}$.

Sytuacja uległa zmianie, gdy w lipcu 1974 r. Nikos Sampson, działający w porozumieniu z rządem w Atenach, dokonał przewrotu zakończonego opanowaniem Nikozji przez rebeliantów, którzy obalili prezy-

\footnotetext{
8 G. Aybet, „Turkey's Long and Winding Road to the EU: Implications for the Balkans", Journal of Southern Europe and the Balkans, Vol. 8, No. 1, s. 72.

${ }^{9}$ A. Mango, The Turks Today, John Muray Publishers, Londyn 2004, s. 60.

${ }^{10}$ S. V. Mayall, „Turkey: Thwarted Ambition”, Institute for National Strategic Studies, National Defence University, Waszyngton 1997, s. 46.

${ }^{11} \mathrm{H}$. Kramer, A Changing Turkey: The Challenge to the Europe and the United States, Brookings Institution Press, Waszyngton 2000, s. 211.

12 President Johnson Letter to Inonu, „Middle East Journal” 1964, Vol. 20, No. 3, s. 354.

${ }^{13}$ H. Kramer, A Changing Turkey..., op. cit., s. 212.

14 K. Ulusoy, op. cit., s. 282.
} 
Michał Alagierski - Relacje Turcji z Unią...

denta Makariosa. W obawie przed turecką interwencją Grecja zwróciła się do Wielkiej Brytanii z propozycją wspólnej operacji w ramach porozumień z 1960 r. Brytyjczycy odmówili, powołując się na międzynarodowe reperkusje mogące wyniknąć z zaangażowania w pacyfikację Cypru15. Turcja wystosowała podobną propozycję, na którą Londyn również nie wyraził zgody. W związku z takim obrotem wydarzeń turecki premier Bülent Ecevit, działając pod wpływem społecznych nacisków, wysłał wojsko, które opanowało tereny na północy Cypru ${ }^{16}$. Politolog William Hale twierdzi, że inwazja zapobiegła inkorporacji Cypru do Grecji, a także samosądom na tureckiej ludności ${ }^{17}$.

Obecność tureckich wojsk zmusiła do reakcji ONZ, która w lutym 1976 r. zainicjowała rozmowy w Genewie oraz w Wiedniu. W rezultacie zawartych porozumień podjęto decyzję o stworzeniu na Cyprze obszarów jednolitych etnicznie, co zamierzano osiągnąć przez akcje przesiedleńcze. $\mathrm{W}$ ten sposób ukształtował się trwały podział wyspy na część grecką i turecką ${ }^{18}$. Jedną z konsekwencji wydarzeń z lipca 1974 r. była również rewizja polityki władz w Atenach, dążących do izolacji międzynarodowej północnego Cypru. W 1981 r., gdy Grecja została przyjęta do Wspólnoty Europejskiej, jej działania skupiły się na wspieraniu starań członkowskich Cypru. W odpowiedzi na pogłębiającą się izolację terenów kontrolowanych przez turecką armię w listopadzie 1983 r. rząd w Ankarze ustanowił Turecką Republikę Cypru Północnego (TRCP). Po tych wydarzeniach ONZ w porozumieniu z EWG przystąpiły do działań, które miały na celu połączenie obu części Cypru. Inicjatywa zyskała akceptację Grecji, jednak została odrzucona przez Turcję, której rząd obawiał się, że inicjatywa posłuży do likwidacji tureckich wpływów ${ }^{19}$. Polityka Ankary zmierzała od tego

\footnotetext{
15 A. Mango, op. cit., s. 73-74.

16 W. Hale, Turkish Foreign Policy 1774-2000, Londyn 2002, s. 181.

17 W, Hale, Turkish Foreign Policy..., op. cit., s. 182.

18 K. Ulusoy, op. cit., s. 282.

${ }^{19}$ New report of the International Crisis Group 2014, http://www.crisisgroup.org.
} 
czasu do zakończenia procesu kształtowania administracji na północy Cypru $^{20}$.

Gdy 3 lipca 1990 r. Cypr złożył wniosek o członkostwo we Wspólnocie Europejskiej, uwidoczniły się w nowej formie problemy wynikające z podziału na dwa odrębne podmioty. Funkcjonowanie podzielonego Cypru w strukturach europejskich stało w sprzeczności z fundamentalnymi zasadami funkcjonowania organizacji. Turcja dostrzegła jednak w tym ostrze polityki wymierzonej w jej wpływy, dlatego władze w Ankarze wystosowały protest, wsparty przez rząd TRCP21. W spór włączyła się ONZ, gdy sekretarz generalny Boutros Ghali potwierdził, że na Cyprze istnieją dwie społeczności, posiadające takie same prawa do sprawowania rządów ${ }^{22}$. Wbrew protestom Turcji w czerwcu 1994 r. na szczycie, który odbył się na Korfu, Komisja Europejska (KE) włączyła Cypr do planu rozszerzenia powołanej w Maastricht Unii Europejskiej23. Wydano dodatkowo deklarację stwierdzającą, że przystąpienie Cypru do Wspólnoty nie będzie uzależnione od nacisków państw trzecich ${ }^{24}$.

Formalne rozmowy z Cyprem zostały otwarte w marcu $1998 \mathrm{r}$. Kształtowanie sprzyjającej podstawy do rozmów zostało uzależnione od porozumienia pomiędzy liderami obu społeczności. Przywódca cypryjskich Turków Rauf Denktaş starał się zablokować możliwość wyłączenia tureckiej społeczności z procesu integracyjnego, mając na uwadze gwarancje udzielone TRPC przez Turcję. Unia Europejska, która wspierała rozmowy dwustronne pomiędzy przedstawicielami obu mniejszości, zdecydowała, że rozmowy akcesyjne rozpoczną się bez względu na powodzenie pertraktacji pomiędzy przedstawicielami cypryjskich Turków i Greków. Data przystąpienia Cypru została ofi-

\section{Ibidem.}

${ }^{21}$ H. Kremer, op. cit. s, 176-177.

22 Rezolucja 649 z 12 marca, United Nations, 1990; Report of the Secretary General to the Security Council, S/23300, United Nations, 19 grudnia 1991.

23 Ibidem.

24 Ibidem. 
Michał Alagierski - Relacje Turcji z Unią...

cjalnie potwierdzona na szczycie unijnym w Amsterdamie w październiku $1997 \mathrm{r}^{25}$.

W 1998 r. w Turcji powołano rząd mniejszościowy, na którego czele stanął Bulent Ecevit. Po wyborach parlamentarnych w kwietniu 1999 r. władzę w państwie przejęła koalicja zdominowana przez Partię Demokratycznej Lewicy. Premier Ecevit wsparł pakiet reform nastawionych na likwidację korupcji, uzdrowienie gospodarki oraz dostosowanie administracji państwa do standardów obowiązujących w Unii Europejskiej. Partia Ecevita utraciła władzę w wyniku przyśpieszonych wyborów parlamentarnych, jednak rządowi udało się zmienić podstawy relacji z Unią Europejską. Reformy postępowały pomimo różnic, jakie dzieliły turecką scenę polityczną ${ }^{26}$.

Efektem nowej polityki wewnętrznej było przyznanie Turcji statusu kandydata na szczycie w Helsinkach w grudniu 1999 r., na którym jednym z kluczowych tematów była kwestia cypryjska ${ }^{27}$. Rada Europejska (RE) uzależniła tempo negocjacji akcesyjnych z Turcją od rozwiązania sporów z Grecją oraz zawarcia porozumienia w sprawie $\mathrm{Cypru}^{28}$. Naciski Brukseli spowodowały zmianę polityki Turcji wobec Cypru, co podkreśla politolog Mustafa Aydin, który wykazuje, że działania instytucji unijnych przyczyniły się zasadniczo do rezygnacji Ankary z polityki przymusu wobec Cypru' ${ }^{29}$. Thomas Diaz dowodzi, że Turcja zdecydowała się poświęcić partykularne interesy za cenę osią-

\footnotetext{
25 Luxembourg European Council 12-13 December 1997. Presidency conclusions.

${ }^{26}$ S. Kinzer, Bülent Ecevit, a Political Survivor Who Turned Turkey Toward the West, Is Dead at 81, "The New York Times", 6 listopada 2006, s. 2.

27 B. Saatçioğlu, Turkey-EU Relations from the 1960s to 2012, [w:] Turkey's Accession to the European Union. Political and Economic Challenges, Lexington Books, Plymouth 2013, s. 10.

${ }^{28}$ W 1987 r. Turcja przystąpiła do negocjacji z Unią. Wniosek zawierał zapis dotyczący zniesienia blokady greckiego Cypru, jednak Ankara zwlekała z wywiązaniem się z obietnic, w związku z tym Komisja Europejska wniosła o zamrożenie negocjacji. Rada Europejska podjęła decyzję, że dopóki Turcja nie wypełni własnych zobowiązań, żaden z ważnych rozdziałów negocjacji akcesyjnych nie zostanie otwarty oraz żaden z pozostałych nie zostanie zamknięty, Artykuł 12 sprawozdania Komisji Europejskiej ze szczytu w Helsinkach, 10-11 grudnia 1999.

${ }^{29}$ M. Aydin, Turkish Foreign Policy Framework and Analysis, SAM Paper, Center for Strategic Research, Ankara 2004, s. 263.
} 
gnięcia nadrzędnego celu, którym było przystąpienie do Unii Europejskiej ${ }^{30}$. W Helsinkach zapadły również wiążące decyzje w sprawie cypryjskich negocjacji akcesyjnych. Potwierdzono wypełnienie zobowiązań nałożonych przez Brukselę ${ }^{31}$. Sprzyjającą sytuację polityczną wsparł również rząd Grecji, na którego czele stał socjalista Kostas Simitis. Podjął on próbę zainicjowania rozmów z Turcją w sprawie Cypru, odstępując od zasady marginalizowania Ankary w stosunkach z Unią 32.

21 czerwca 1999 r. w Kolonii odbyło się spotkanie przywódców państw grupy G8, na którym podjęto decyzję o wprowadzeniu w życie rezolucji 1250 Rady Bezpieczeństwa ONZ dotyczącej Cypru. Na jej podstawie RB wyznaczyła termin negocjacji z udziałem delegacji Greków i Turków cypryjskich. Wezwano strony do współdziałania z sekretarzem generalnym w jego dążeniach do zakończenia sporu. Deklaracja uwzględniła porozumienie zawarte 20 czerwca pomiędzy premierem Ecevitem i prezydentem TRCP Raufem Denktaşem, w którym obaj politycy uznawali integrację Cypru za nadrzędny cel polityczny ${ }^{33}$.

Na szczycie w Kolonii doszło do spotkania ministra spraw zagranicznych Grecji Jorgosa Papandreu z szefem dyplomacji Turcji Ismailem Cemem. Dyskutowano na temat spornych kwestii w grecko-tureckich relacjach oraz o przyszłości Unii. Dzięki konsultacjom zawarto porozumienie, które zaowocowało uznaniem tureckich aspiracji unijnych. W zamian za obietnicę rezygnacji z zablokowania tureckiego wniosku Ateny domagały się porozumienia w sprawie spornej granicy na Morzu Egejskim, co miało zapobiec napięciom we wzajemnych

30 T. Diaz, The Imposition of Governance: Transforming Foreign Policy through EU Enlargement, Copenhagen Peace Research Institute, 2000, s. 12.

31 Zobacz paragraf 9 (b), Presidency Conclusions, Helsinki European Council, 10-11 września 1999 r.

32 G. Aybet, M. Muftuler-Bac, Transformations in Security and Identity after the Cold War: Turkey's Problematic Relationship with Europe , „International Journal” 2000, Vol. 55, s. 534.

${ }^{33}$ European Commission, Regular Report from the Commission on Progress towards Accession Turkey, B. Criteria for Membership, Political Criteria, The Cyprus issue, 13 października 1999, http://europa.ue/enlargement/turkey. 
Michał Alagierski - Relacje Turcji z Unią...

relacjach. Spór miał zostać oddany pod jurysdykcję Międzynarodowego Trybunału Sprawiedliwości w Hadze do 2004 r. Papandreu domagał się również zgody Turcji na kandydaturę Cypru do Unii ${ }^{34}$. Poruszono kwestię wykonania wyroku Europejskiego Trybunału Praw Człowieka w Strasburgu (ETCP) z 1996 r., który wzywał Turcję do uregulowania kwestii odszkodowań za majątek cypryjskich Greków znajdujący się na obszarze TRCP35. ETCP domagał się również wyjaśnienia sprawy osób zaginionych po $1974 \mathrm{r}^{36}$.

Wynik dotychczasowych osiągnięć dyplomatycznych ułatwił działanie ONZ, która 11 listopada 2002 r. przedstawiła kompleksowy plan rozwiązania konfliktu na Cyprze. Zakładał on utworzenie federacji po przeprowadzeniu powszechnego referendum ${ }^{37}$. Plan objął patronatem sekretarz generalny ONZ Kofi Annan. Zakładał on, iż zjednoczenie Cypru ma bezpośredni związek z negocjacjami akcesyjnymi z Brukselą, ustalając, że w wypadku braku zgody na utworzenie federalnego państwa do Unii miała wejść grecka Republika Cypru. W takim wypadku „plan Annana” przewidywał pozostawienie tureckiej mniejszości poza strukturami unijnymi oraz utrzymanie międzynarodowej izolacji TRCP ${ }^{38}$. Warunki przedstawione przez ONZ naruszały interes Turcji, a w opinii politologów, w tym profesora Bilala Şimşira, świadomie dyskryminowały mniejszość turecką 39 .

Turcja stanęła przed poważnym dylematem, gdyż od decyzji w sprawie polityki wobec Cypru zależała przyszłość tureckich negocjacji akcesyjnych. Fundamentalne znaczenie należy przypisać wyborom parlamentarnym, które odbyły się w Turcji w listopadzie $2002 \mathrm{r}$. Zwycięska Partia Sprawiedliwości i Rozwoju (AKP) oraz jej lider Recep Tayyip Erdoğan reprezentujący idee religijne i konserwatywne

34 T. Panayotis, D. Thantos, op. cit., s. 113.

35 Ibidem.

${ }^{36}$ Commission Staff working Document: Turkey 2008 progress report, s. 13, http://ec.europa.eu.

37 A. Aydintaşabaș, Uniting Cyprus: A Settelment that Needs a Final Pusch, „International Herald Tribune", 3 luty 2004.

38 A. A. Celenk, op. cit., s. 354.

39 B. Şimşir, $A B, A K P$ ve Kıbrıs, Bilgi Yajınevi, Ankara 2003, s. 59. 
budzili obawy, iż nowy rząd odrzuci możliwość porozumienia w kwestii Cypru. Rzeczywistość pokazała, że przypuszczenia te nie odpowiadały faktycznym zamiarom, gdyż już 21 listopada 2002 premier Erdoğan oznajmił, że Turcja nie zamierza blokować możliwości rozwiązania kwestii cypryjskiej40. Znaczenie tej polityki partii rządzącej przedstawił minister spraw zagranicznych Turcji Yaşar Yakış podczas przemówienia inauguracyjnego do zgromadzenia narodowego w Ankarze. Podkreślił w nim, że ustępstwa w sprawie Cypru stanowią wkład Turcji w rozwój stosunków z Unią ${ }^{41}$. Ayse Aslihan Celenk, który zajmuje się polityką zagraniczną Erdoğana, dowodzi, że strategia AKP miała na celu zagwarantowanie interesów cypryjskich Turków bez szkody dla tureckich aspiracji unijnych ${ }^{42}$. Profesor Uniwersytetu w Ankarze Mümtaz Soysal podkreśla, że Turcja wykazała ogromną dojrzałość polityczną, dostrzegając konieczność zmiany dotychczasowej strategii wobec Cypru. Powołał się w swej opinii na przykład potępienia przez turecki rząd przywódcy Denktaşa, który zorganizował na Cyprze ogromną demonstrację przeciwko polityce Unii ${ }^{43}$.

Politolog Burhanettin Duran przypisuje doniosłą rolę w realizowaniu nowej polityki rządowi Erdoğana ${ }^{44}$, przychylając się do zdania, iż stosunki zewnętrzne AKP stanowią najbardziej zrównoważoną sferę działania rządu. Architektem relacji Turcji na arenie międzynarodowej był Ahmet Davutoğlu, który początkowo pełnił funkcję szefa doradców premierów Güla i Erdoğana. W 2009 r. otrzymał stanowisko ministra spraw zagranicznych, które dzierżył do momentu objęcia funkcji premiera w sierpniu 2014 r. Stworzył w tym czasie podstawę doktryny, którą definiowały hasła „zero konfliktów z sąsiadami” oraz „głębia strategiczna” i polityka „soft power”. W ramach tych założeń

40 Erdoğan: Şahinlik Sonuç Vermez, „Hürriyet”, 21 listopada 2002.

${ }^{41}$ S. B. Gülmez, The Cyprus Policy of the CHP: Change Or Continuation, Insight Turkey, „Ancara Center for Turkish Policy Studies”, Vol. 9, No. 1, 2007, s. 129.

42 A. A. Celenk, op. cit., s. 351.

${ }^{43}$ M. Soysal, The Future of Turkish Foreign Policy, [w:] L. G. Martin, M. Soysal, The Future of Turkish Foreign Policy, MA: MIT Press, Cambridge 2002, s. 37-46.

${ }^{44}$ H. Yavuz, The Emergence of a New Turkey: Democracy and the AKP Party, University of Utah Press, Salt Lake City 2006, s. 281-294. 
Michał Alagierski - Relacje Turcji z Unią...

Turcja miała stanowić łącznik pomiędzy Unią Europejską i Bliskim Wschodem. Koncepcja Davutoğlu odwoływała się do polityki czasów osmańskich, kiedy Anatolia stanowiła serce imperium. Powstała dzięki temu spójna teoria polityczna, stymulująca rozwój państwa, odwołująca się jednocześnie do idei wzmocnienia bezpieczeństwa międzynarodowego. Wkład w rozwiązanie problemów na Bliskim Wschodzie miał również przysłużyć się dążeniu Turcji do przystąpienia do Unii Europejskiej ${ }^{45}$. W koncepcji forsowanej przez AKP mieściły się założenia, które odpowiadały podziałom społecznym w Turcji. Nieangażowanie się w spory międzynarodowe miało na celu zaspokojenie ambicji wyborców, którzy pamiętali o głównej zasadzie polityki Turcji od czasów Kemala Atatürka, z drugiej strony konserwatywna AKP włączyła do doktryny Davutoğlu kraje muzułmańskie. Podkreślając znaczenie islamu w polityce państwowej, Turcja rozszerzyła swą działalność w ramach Organizacji Współpracy Islamskiej. Rząd podkreślał także priorytetową rolę relacji ze Stanami Zjednoczonymi ${ }^{46}$.

Siły opozycji parlamentarnej w Turcji wykorzystały koncepcje AKP, próbując wywołać w społeczeństwie nastroje antyrządowe. Przewodniczący Republikańskiej Partii Ludowej (CHP) Deniz Baykal w przemówieniu do zgromadzenia narodowego z 17 listopada 2002 r. stwierdził, iż rząd Erdoğana ugiął się pod wpływem unijnego ultimatum ${ }^{47}$. Lider opozycji skrytykował pracę ministra spraw zagranicznych Yakışa, który zdaniem Baykala prowadził działania zmierzające do usunięcia tureckich wojsk z północy Cypru, co było tym samym sprzeczne $\mathrm{z}$ racją stanu. Dodatkowo podkreślał, że przystąpienie Cypru do Unii pozbawi ochrony turecką mniejszość ${ }^{48}$. Baykal wskazywał, że „plan Annana" umożliwi greckiej społeczności przejmowanie ziemi należącej do Turków, dlatego nawoływał do odroczenia przystąpienia Cypru do Unii do momentu, w którym interesy ludności tureckiej zostaną w pełni zabezpieczone. Postulował także oddzielenie kwestii cypryj-

\footnotetext{
45 K. Öktem, Angry Nation: Turkey since 1989, Zed Books, Londyn 2011, s. 170.

46 Ibidem, s. 171.

47 I. Cem, Turkey's Cyprus Policy, „Northen Cyprus Monthly”, listopad 2002.

48 Baykal - Yakış Düellosu, „Turkish Daly News”, 12 listopada 2002.
} 
skiej od tureckich negocjacji akcesyjnych ${ }^{49}$. W zamian proponował, aby rząd powoływał się w rozmowach z Unią na umowy z 1960 r., uniemożliwiające włączenie Cypru do organizacji, której Turcja nie była członkiem ${ }^{50}$.

Od początku istnienia republika opiera się na kontrolującej roli armii. Problem Cypru, który wpływał na bezpieczeństwo tureckie, musiał zatem zyskać aprobatę przedstawicieli sił zbrojnych. Jak twierdzi profesor Gulnur Aybet, dowództwo wojskowe przez lata wymuszało na politykach działania zgodne z założeniami strategicznymi, w których Cypr odgrywał szczególną rolę51. Według Aybeta w 2002 r. w sprawie Cypru doszło do sporu polityków AKP z generałami ${ }^{52}$. Dowódca sił lądowych Aytac Yalman stwierdził, że „plan Annana” godzi w bezpieczeństwo kraju, a jego konsekwencją będzie „osaczenie Turcji w granicach Anatolii" 53. Naczelne dowództwo nie wierzyło, że ustępstwa w kwestii Cypru przyśpieszą tureckie negocjacje z Unią54. Zdanie to zdają się potwierdzać politolodzy Ziya Onis i Suhnaz Yilmaz, którzy dostrzegają $w$ polityce Unii tendencje do wykorzystywania tureckich aspiracji ${ }^{55}$. Z kolei Philip Robins twierdzi, że decyzje Brukseli w sprawie Cypru były w tamtym czasie sprzeczne z zasadą mówiącą, że do wspólnoty nie mogą przystąpić państwa, które nie stosują się do układów międzynarodowych ${ }^{56}$.

W odpowiedzi na zarzuty wobec polityki cypryjskiej rządu premier Erdoğan podkreślił odpowiedzialność poprzedników, wykazując, iż

${ }^{49}$ Ibidem, s. 131.

50 0. Oymen, Turkey's European Foreign Policy, Perceptions, „Journal of International Affairs" 1997, Vol. 2, s. 3.

51 G. Aybet, Turkey and the EU After the First Year of Negotiations: Reconciling Internal and External Policy Challenges, „Security Dialogue” 2006, Vol. 37, No. 4, 533.

52 Ibidem.

53 „Turkish Daly News”, 1 stycznia 2003; „Cumhurriyet”, 5 stycznia 2004; „Turkish Daly News", 8 stycznia 2004.

${ }^{54}$ Wywiad z dowódcą sztabu generalnego tureckiej armii, Hilmim Ozkokiem przeprowadzony przez Mehmeta Alego Kislaliego, „Radical”, 9 listopada 2003.

55 Z. Onis, S. Yilmaz, op. cit., s. 24.

56 P. Robins, Between the EU and the Middle East: Turkish Foreign Policy under the AKP Government, 2002-2007, „ISPI Working Paper”, Mediolan 2007, s. 11. 
Michał Alagierski - Relacje Turcji z Unią...

nie zabezpieczyli oni w należyty sposób interesu narodowego Turcji, doprowadzając do tego, że rząd AKP działa pod przymusem sytuacji międzynarodowej. Premier tłumaczył, że brak elastycznej polityki przez lata stworzył sytuację, w której jedyną możliwością stało się uwzględnienie aspiracji greckich Cypryjczyków, wspartych dodatkowo przez Unię Europejską57. Pod wpływem napiętej sytuacji międzynarodowej oraz wewnętrznej rząd Erdoğana zaproponował rozwiązanie kwestii cypryjskiej oparte na kazusie Belgii, umożliwiającym współżycie dwóch społeczności funkcjonujących w ramach jednego państwa ${ }^{58}$.

Pod wrażeniem ugodowej polityki AKP w 2002 r. Komisja Europejska wydała dokument, w którym wyraziła zadowolenie z reform przeprowadzonych przez Turcję od czasu szczytu w Helsinkach, uznając, że Ankara spełnia unijne kryteria. 0 przyszłości tureckiego wniosku miał jednak zdecydować szczyt Unii, który został wyznaczony na grudzień 2002 r. w Kopenhadze ${ }^{59}$. Rząd Erdoğana uzależnił wprowadzenie dalszych reform od decyzji, które miały tam zapaść 60 . Rozmowy w Kopenhadze odbiegały od wcześniejszych deklaracji, w konsekwencji nie doszło do wyznaczenia daty przystąpienia Turcji do Unii. W zamian władze Wspólnoty postanowiły dokonać rewizji umów stowarzyszeniowych, powołując się na niewystarczające tempo przemian w Turcji61. Potwierdzono również wcześniejsze decyzje w sprawie Cypru, deklarując, iż w razie fiaska rozmów w sprawie zjednoczenia

57 S. B. Gülmez, op. cit., s. 134.

58 A. A. Celenk, op. cit., 351.

${ }^{59}$ European Council Documents: 2002b, para. 6, 2002c, para. 25.

60 Z. Öniş, The Political Economy of Islam and Democracy in Turkey: From the Welfare Party to the AKP, [w:] D. Jung, Democratization and Development: New Political Strategies for the Middle East, New York 2006, s. 103-128.

61 Z. Öniş, The New Wave of Foreign Policy Activism in Turkey: Drifting Away from Europeanization?, DIIS Report 05. Copenhagen: Denish Institute for International Studies, 2009. W 1963 r. W. Hallstein ówczesny przewodniczący KE oświadczył: „Turcja jest częścią Europy. (...) Turcja powinna być pełnoprawnym członkiem Wspólnoty". W podobnym duchu wypowiadał się kanclerz RFN K. Adenauer, traktujący Turcję jako „oczywistego partnera europejskiego, któremu nie powinno odmawiać się możliwości członkostwa”. 
rozmowy akcesyjne obejmą jedynie Republikę Cypru. W takim wypadku Bruksela zobowiązywała się do udzielenia pomocy ekonomicznej dla TRCP. Jednocześnie odrzucony został postulat Turcji dotyczący uznania przez Unię państwa cypryjskich Turków ${ }^{62}$.

Podczas kopenhaskiego szczytu Komisja Europejska po raz pierwszy przyznała, że akcesja Turcji zagraża Wspólnocie. Zwrócono uwagę na kwestie odmienności religijnej, a także na związane z tym trudności w relacjach pomiędzy Turcją a pozostałymi członkami Unii63. W gronie oponentów przystąpienia Turcji do Unii znajdowali się przywódcy najsilniejszych państw europejskich, kanclerz Niemiec Angela Merkel oraz prezydent Francji Nicolas Sarkozy. Przywódcy ci stali się wyrazicielami grupy europejskich polityków, którzy także dostrzegali zagrożenia związane z członkostwem Turcji. Wskazanie przez kanclerz Merkel problemu tureckiej emigracji ściśle wiązało się z ogromną mniejszością turecką w Niemczech. Znamienne jest, że kwestia ta została przedstawiona jako podrzędna wobec zagadnienia nieprzestrzegania przez Turcję praw człowieka oraz blokowania przez Ankarę rozwiązania problemu cypryjskiego. Prezydent Sarkozy sprzeciwiał się członkostwu Turcji z podobnych powodów. Dostrzegając problem przyrostu muzułmańskiej mniejszości we Francji, uznał, że muzułmanie nie mogą zyskać punktu oparcia w Turcji jako członku Unii64. Obawy Niemiec i Francji potwierdzali prawicowi politycy w Europie, wskazując na radykalizm islamski, względy gospodarcze oraz społeczne, wynikające z przystąpienia Turcji do Unii 65 . W zamian za odroczenie negocjacji Niemcy zaproponowały Turcji projekt ustanowienia

${ }^{62}$ European Council, 2002b, Presidency Conclusions, Kopenhaga, 12-13 grudnia.

63 European Commission Document, 2004b, paragraf 4-5.

${ }^{64}$ B. Saatçioğlu, Turkey-EU Relations from the 1960s to 2012, in Turkey's Accession to the European Union. Political and Economic Challenges, Plymouth 2013, s. 14.

${ }^{65}$ EU Puts Turkey on a Long Road to Accession: Commission Gives an Amber Light for Entry; Talks to Start, but They Will Stop If Rights Are Violated, 7 października 2004; "Guardian”, 7 października 2004; In 1683 Turkey Was the Invader. In 2004 Much of Europe Still Sees It That Way, „Guardian”, 22 września 2004. 
Michał Alagierski - Relacje Turcji z Unią...

specjalnych stosunków, który wpisywałby się w istniejące porozumienia Wspólnoty w ramach Europejskiej Strefy Ekonomicznej (EEC) ${ }^{66}$.

Rozmowy prowadzone w Kopenhadze wzbudzały szczególne zainteresowanie tureckiej mniejszości na Cyprze. Rozwiązania przyjęte na szczycie doprowadziły do zmiany stanowiska liderów TRPC. W grudniu 2003 r. odbyły się wybory parlamentarne, w których zwyciężyli zwolennicy przystąpienia Cypru do Unii. Ankara niechętnie odniosła się do wzrostu znaczenia tych polityków, uznając, że spowoduje to spadek znaczenia Turcji jako wyraziciela interesów mniejszości tureckiej na Cyprze. Spotkanie ministra spraw zagranicznych Güla z przedstawicielami władz TRCP w kwietniu 2004 r. pokazało, że rząd Turcji nie zamierzał prowadzić szczegółowych konsultacji. W rezultacie prezydent Turcji Ahmet Necdet Sezer przyznał, że nie jest dostatecznie poinformowany o sytuacji na Cyprze ${ }^{67}$. Na premiera Erdoğana spadła fala krytyki po przemówieniu prezydenta Denktaşa, który wyraził sprzeciw wobec zgody Turcji na przeprowadzenie referendum na Cyprze. Według Denktaşa już po ogłoszeniu „planu Annana” AKP zaczęła odcinać się od twardej linii politycznej wobec cypryjskich Greków, którą kolejne rządy w Ankarze prowadziły od 1974 r.68. W wywiadzie dla tureckiej telewizji Denktaş oskarżył premiera Erdoğana o poświęcenie Cypru na rzecz członkostwa Turcji w Unii69.

Krytyczne głosy wobec polityki rządu narastały wraz ze zbliżaniem się terminu referendum przewidzianego na początek maja $2004 \mathrm{r}$. W kwietniu minister Gül stwierdził podczas przemówienia w Parlamencie, że Turcja zaprzepaściła możliwość zablokowania akcesji Cypru do Unii w 1995 r., kiedy rząd pani premier Tansu Çiller zgodził

${ }^{66}$ Gazeta „Milliyet” opublikowała tekst pod kątem rozszerzenia UE o grupę państw Europy środkowo-wschodniej: „nie wyobrażam sobie sytuacji, w której kraje postkomunistyczne wejdą do UE, podczas gdy Turcja, która przez lata była częścią walczącego z komunizmem obozu zachodniego, zostanie na lodzie.(...)", zob.: J. Varvick, K.-O. Lang, European Neighbourhood Policy: Challenges for the EU-Policy Toward the New Neighbours, Farmington Hills, Barbara Budrich Publishers, s. 197-216.

${ }^{67}$ Sezer: Türkiye’nin Kabul Ettiği Davos Tutanağından Öğrenildi, „Milliyet” 14 kwietnia 2004.

68 S. B. Gülmez, op. cit., s. 132.

69 „Turkish Daly News”, 3 stycznia 2003. 
się na negocjacje w zamian za przyjęcie Turcji do Unii Celnej. W tym samym przemówieniu Gül wskazał, że w 1999 r. Turcja przyjęła status obserwatora we Wspólnocie w zamian za potwierdzenie deklaracji z 1995 r. $^{70}$. Philip Gordon wskazał podobną tendencję w przypadku rządu Erdoğana, dowodząc, że AKP zrezygnowała z twardego stanowiska wobec Cypru w zamian za wizję ułatwienia negocjacji z Unią ${ }^{71}$.

Referendum w sprawie akcesji do Unii przeprowadzono 24 kwietnia 2004 r. Wynik głosowania wywołał poruszenie międzynarodowej opinii publicznej, gdyż okazało się, że grecka ludność Cypru odrzuciła możliwość wstąpienia do Unii wspólnie z Turkami z północy. W rezultacie referendum uniemożliwiło zjednoczenie Cypru ${ }^{72}$. W odpowiedzi premier TRCP Mehmet Ali Talat zaapelował do Unii oraz ONZ o zniesienie sankcji gospodarczych, a także o uznanie międzynarodowe, powołując się na fakt, iż Turcy opowiedzieli się w referendum za zjednoczeniem ${ }^{73}$. Władze $\mathrm{w}$ Ankarze wydały oświadczenie, w którym wskazywano, iż Turcja uczyniła wszystko, aby doprowadzić do zjednoczenia ${ }^{74}$. Politolog Nathalie Tocci przychyla się do tej opinii, twierdząc jednocześnie, że to polityka Unii przyczyniła się do utrwalenia podziału wyspy. Tocci dodatkowo dowodzi, że Bruksela świadomie działała przeciwko przyjęciu do Unii ludności tureckiej w obawie przed przeniesieniem sporów na Cyprze do polityki wewnętrznej Wspólnoty ${ }^{75}$.

Dopiero 1 maja 2004 r., kiedy Republika Cypru oficjalnie stała się członkiem Unii Europejskiej, władze unijne zdecydowały się na krytykę postawy cypryjskich Greków w referendum. W konsekwencji powstało porozumienie pomiędzy Stanami Zjednoczonymi, Unią Europejską oraz ONZ dotyczące nowej strategii zjednoczenia Cypru. Zakła-

${ }^{70}$ A. A. Celenk, op. cit., 354.

${ }^{71}$ P. Gordon, Turkey on the Brink, „The Washington Quarterly” 2006, Vol. 29, No. 3, s. 63.

72 In Quotes: Cyprus Reunification Fails, „BBC News”, 24 kwietnia 2004.

73 Ibidem.

74 Ibidem.

75 N. Tocci, Anchoring Turkey to the European Union: The Domestic and Foreign Policy Challenges Ahead, Florence 2004, s. 199. 
Michał Alagierski - Relacje Turcji z Unią...

dało ono nakłonienie stron konfliktu do przystąpienia do rozmów dzięki zastosowaniu obustronnych restrykcji ekonomicznych, polegających na utrzymaniu izolacji północnego Cypru oraz zmniejszeniu pomocy gospodarczej dla Republiki Cypru ${ }^{76}$. Philip Robins rzuca inne światło na te deklaracje, przytaczając raport sekretarza generalnego ONZ z 28 maja 2004 r., zgodnie z którym postawa cypryjskich Turków miała zostać nagrodzona udzieleniem daleko idącej pomocy ekonomicznej77. Robins twierdzi, że w rzeczywistości Bruksela nie planowała nigdy zniesienia sankcji wobec TRPC, natomiast deklaracje dotyczące zjednoczenia Cypru miały jedynie doprowadzić do złagodzenia polityki Turcji ${ }^{78}$.

Zgoda na rozszerzenie Unii wytrąciło z rąk rządu Erdoğana kluczowy argument $w$ rozmowach dotyczących przystąpienia Turcji do Wspólnoty. W grudniu 2004 r. na szczycie w Brukseli Unia Europejska wznowiła negocjacje z Turcją, zaznaczając, że akt ten nie jest jednoznaczny z ich szybkim zakończeniem ${ }^{79}$. Już w lipcu 2005 r. Bruksela wywarła nacisk na turecki rząd, aby podpisał dodatkowy protokół do porozumienia akcesyjnego, obligujący Turcję do usankcjonowania ścisłych stosunków z nowymi członkami Unii. Premier Erdoğan podpisał dodatkowy protokół, jednak zastrzegł w nim, że nie uzna Republiki Cypru oraz że nie zostaną zniesione bariery handlowe nałożone na ten kraj, dopóki Unia nie uzna TRCP80.

W opinii planisty Departamentu Stanu Henriego Barkeya Unia wykorzystała instrumenty nacisku w celu zabezpieczenia Republiki Cypru przed ingerencją Turcji. W tym kontekście odmowa uznania pozostawała jedynym argumentem w rękach Ankary. Stanowcza postawa

76 P. Robins, op. cit., s. 12.

77 Ibidem.

78 Ibidem.

${ }^{79}$ European Council 2004, Conclusions of the Brussels European Council, 16-17 grudnia 2004, 16238/1/04 REV 1.

80 European Commission 2006, Enlargement Strategy and Main Challenges 20062007, including annexed special report on the EU's Capacity to Integrate New Members, COM (2006) 649 final, Brussels; EU Leaders Raise Red Flag on Turkey, „New York Times”, 5 października 2005; F. Schimmelfennig, U. Sedelmeier, The Politics of European Union Enlargement: Theoretical Approaches, Nowy Jork 2005, s. 120-141. 
Brukseli doprowadziła w grudniu 2006 r. do zawieszenia negocjacji członkowskich z Turcją81. Premier Erdoğan przyznał w związku z tym, że jego kraj nie może przystać na jednostronne ustępstwa wsparte politycznym szantażem ${ }^{82}$. Unijny Komisarz ds. rozszerzenia Olli Rehn wyjaśniał, że spełnienie warunków postawionych przez Brukselę spowoduje ponowne otwarcie negocjacji. Kwestia uznania Republiki Cypru została przemilczana ze względów strategicznych, liderzy unijni zdawali sobie sprawę z twardego stanowiska Ankary, próbując skupić działania na kwestiach mniejszej wagi83.

W listopadzie 2007 r. Parlament Europejski wydał rezolucję wzywającą Turcję do zdjęcia embarga na handel z Republiką Cypru. W dokumencie umieszczono klauzulę, która stwierdza, iż ustępstwo $\mathrm{w}$ tej kwestii wpłynie na odblokowanie rozmów akcesyjnych ${ }^{84}$. W tym samym czasie Ankara podniosła kwestię niezrealizowanych deklaracji unijnych wobec TRPC związanych z włączeniem izolowanej części Cypru w program pomocy gospodarczej85. Bruksela tłumaczyła, że tureckie restrykcje wobec Republiki Cypru stanowią niedopuszczalną formę nacisku i nie mogą wpływać na politykę Unii ${ }^{86}$. Grecka minister spraw zagranicznych Dora Bakoyannis oskarżyła Turcję o prowadzenie podwójnej polityki, wskazując, iż Ankara dąży do intensywnej wymiany handlowej z Unią, jednocześnie pozbawiając tego prawa jednego z członków Wspólnoty87.

W 2008 roku miała miejsce decydująca runda rozmów, zainicjowanych przez sekretarza generalnego ONZ Ban Ki-moona. Celem tej inicjatywy było doprowadzenie do zjednoczenia Cypru. Turcja podobnie

${ }^{81}$ H. J. Barkey, O. Taspinar, Turkey: On Europe's Verge, „The Foreign Policy Association", 2006, s. 16.

82 Ibidem.

83 Wywiad z Ollim Rehnem z 29 listopada 2006 r., www.abhaber.com/haber. php?id=14844 [dostęp: 15.02.2015].

${ }^{84}$ D. Dombley, „Financial Times”, 11 grudnia 2006.

85 N. Watt, „Guardian”, 12 grudnia 2006.

86 „Enlargement Newsletter”, 5 listopada 2007.

87 Dora Bakoyannis, Does Europe have a message for the world?, „Annual Lecture of Eastern Europe Center”, St. Anthony's College, University of Oxford, 6 listopada 2007. 
Michał Alagierski - Relacje Turcji z Unią...

jak w kontaktach z Brukselą występowała w roli faktycznego reprezentanta nieuznawanej TRPC. Podczas negocjacji ustalono, iż panuje zgoda co do zagadnień dotyczących przyszłego statusu Cypru oraz systemu rządów po zjednoczeniu. Problematyczne kwestie dotyczyły odszkodowań za grecki majątek przejęty po inwazji tureckiej w $1974 \mathrm{r}$. oraz rekompensaty dla uchodźców. Kolejne przeszkody związane były z prawnym statusem Turków, którzy zasiedlili wyspę po $1974 \mathrm{r}$. Turcja wskazywała również na kwestie bezpieczeństwa w regionie, otwierając debatę na temat obecności tureckich żołnierzy na północy Cypru. Pertraktacje utkwiły w martwym punkcie ze względu na brak porozumienia w kwestiach zasadniczych ${ }^{88}$.

W 2009 r. rozpoczęły się rozmowy z udziałem przedstawicieli TRCP oraz władz Republiki Cypru ${ }^{89}$. Osiągnięcie porozumienia uzależniono przede wszystkim od realizacji postanowień porozumienia z Ankary z 2008 r., w którym Turcja potwierdziła gotowość otwarcia portów dla towarów pochodzących z Republiki Cypru w zamian za obietnicę odblokowania negocjacji z Unią ${ }^{90}$. Rozmowy nie przyczyniły się do zmiany sytuacji, potwierdzając impas. Według profesor Gulnur Aybet rząd AKP zdecydował się w tym czasie na realizację planu minimum wobec tureckiej enklawy na Cyprze. Przede wszystkim zacieśnione zostały związki północnego Cypru z Turcją, jednocześnie Ankara wzmocniła iluzoryczną formę międzynarodowego uznania TRPC przez kraje należące do Organizacji Współpracy Islamskiej ${ }^{91}$.

W 2011 r. do mediów przedostała się informacja dotycząca możliwości użycia przez Turcję marynarki wojennej przeciwko Republice Cypru. Nie miała znamion realnego zagrożenia, pokazała jednak, jakie możliwości wywierania nacisku posiada Ankara. Kwestia dotyczyła nowego czynnika w relacjach cypryjskich, którym było odkrycie boga-

${ }^{88}$ H. Pope, The EU-Turkey-Cyprus Triangle: Setting the Stage, ICG, 23 lutego 2009; International Crisis Group, Solving the EU-Turkey-Cyprus Triangle, Istanbul/Brussels, 23 lutego 2009.

${ }^{89}$ H. Pope, op. cit.

90 European Commission, Turkey 2008 Progress Report.

91 G. Aybet, op. cit., s. 73. 
tych złóż gazu w obszarze wód terytorialnych Republiki Cypru. Turcja zastrzegła, że złoża stanowią wspólną własność wszystkich Cypryjczyków, w związku z tym TRPC ma prawo partycypować w zyskach $\mathrm{z}$ ich wydobycia ${ }^{92}$.

W maju 2012 Bruksela zaproponowała Turcji nową formę współpracy, określoną mianem „pozytywnej agendy”. Od momentu zawieszenia negocjacji akcesyjnych był to jedyny mechanizm podtrzymujący formalne stosunki Turcji z Unią. W ramach projektu powołano przedstawicieli obu stron odpowiedzialnych za monitorowanie obszarów negocjacyjnych. Specjalnie przygotowane grupy robocze miały rejestrować postępy w zakresie energetyki, mobilności, migracji, praw człowieka, reform politycznych oraz wymiaru sprawiedliwości, a także współpracy w zwalczaniu terroryzmu oraz polityki zagranicznej. Turcja zgodziła się na współpracę w ramach „pozytywnej agendy”, uznając tego typu relacje za stan przejściowy ${ }^{93}$. W drugiej połowie 2012 r. nastąpił kolejny kryzys w stosunkach Unii z Turcją. Powodem wzrostu napięć stało się przejęcie prezydencji Cypru w Radzie Unii Europejskiej. Ankara zdecydowała się wywrzeć nacisk na Wspólnotę przez zbojkotowanie prezydencji cypryjskiej. Strategia ta doraźnie miała przyczynić się do złagodzenia unijnego stanowiska w kwestii zniesienia wiz dla tureckich obywateli94.

\section{Podsumowanie}

Próby zdominowania Cypru zostały zdeterminowane przez nieustającą konfrontację rywalizujących potęg. Współczesne zależności

92 Report of the Secretary General on his mission of good offices, 12 marca 2012, www.uncyprus talks.org/nqcontent.cfm?a_id=2486\&tt=graphic\&lang=1, z dnia 25 lutego 2015.

${ }^{33}$ S. Ananicz, Prezydencja Cypryjska a relacje Turcji z Uniq, Ośrodek Studiów Wschodnich im. Marka Karpia, http://www.osw.waw.pl/pl/publikacje/komentarzeosw/2012-06-26/prezydencja-cypryjska-a-relacje-turcji-z-unia-europejska [dostęp: 25.02.2015].

${ }^{94}$ S. Ananicz, Prezydencja cypryjska a relacje Turcji z UE, komentarze OSW nr 82 $\mathrm{z}$ dnia 1 czerwca $2012 \mathrm{r}$. 
Michał Alagierski - Relacje Turcji z Unią...

występujące w polityce międzynarodowej kumulują się, sprawiając, że z pozoru marginalny uczestnik stosunków międzynarodowych urasta do znacznej rangi. Dziś kwestia cypryjska angażuje siły poważnych podmiotów aspirujących do roli potęg regionalnych, a nawet światowych. Już dawno rywalizacja na Cyprze ewoluowała poza konflikt grecko-turecki. Włączenie się do rozgrywki Unii Europejskiej nastąpiło kosztem pozycji Turcji, której nie udało się w pełni uniknąć kosztów związanych z chęcią utrzymania wpływów na Cyprze. Koszty ponosi również Unia Europejska, której udało się włączyć Cypr do własnej strefy wpływów, a jednak nadal boryka się z widmem własnych ambicji. Konflikt interesów Turcji i Unii Europejskiej wedle wszelkich ocen sięga dalej niż rywalizacja na obszarze Cypru i choć łatwo wskazać poważniejsze cele, problem cypryjski dzieli Brukselę i Ankarę w sposób znaczący. W pewnym sensie cypryjski dramat pozwala dostrzec poważniejsze przeszkody w relacjach dwustronnych do tego stopnia, że demaskuje niechęć, która stanowi prawdziwą przeszkodę w integracji Turcji z Unią Europejską. Gdy zastanawiamy się nad przyszłością Cypru, przychodzi na myśl pytanie o sens tureckiej obecności w strukturach europejskich. Można mniemać, iż na podstawie perturbacji wokół Cypru jesteśmy w stanie podjąć się odpowiedzi na często zadawane pytanie, jaki jest rzeczywisty powód odrzucania aspiracji Turcji do przystąpienia do Unii Europejskiej.

\section{Bibliografia:}

\section{Źródła:}

BBC News, „In Quotes: Cyprus Reunification Fails” 2004.

European Commission, Enlargement Strategy and Main Challenges 20062007, including annexed special report on the EU's Capacity to Integrate New Members, COM (2006) 649 final, Brussels.

European Commission, Regular Report from the Commission on Progress towards Accession Turkey, B. Criteria for Membership, Political Criteria, The Cyprus issue 1999 ( tekst dostępny: http://europa.ue/enlargement /turkey). 
Hürriyet, Erdoğan: Şahinlik Sonuç Vermez, 2002.

European Council 2004, Conclusions of the Brussels European Council, 16-17 XII 2004, 16238/1/04 REV 1.

European Council Documents: 2002b, para. 6, 2002c, poz. 25.

European Council, Presidency Conclusions, Kopenhaga, 12-13 XII 2002.

New report of the International Crisis Group 2014 (tekst dostępny na stronie: http://www.crisisgroup.org).

Presidency Conclusions, Helsinki European Council, poz. 9 (b), 10-11 IX 1999.

"Report of the Secretary General on his mission of good offices”, 12 III 2012, (tekst dostępny na stronie: http//www.uncyprus talks.org/nqcontent. cfm?a_id= 2486\&tt=graphic\&lang=1).

Wywiad z Ollim Rehnem z 29 XI 2006, (tekst dostępny: www.abhaber.com/ haber.php?id=14844) (stan na dzień 15 II 2015).

\section{Publikacje zwarte, artykuły:}

Ananicz S., Prezydencja Cypryjska a relacje Turcji z Uniq, Ośrodek Studiów Wschodnich im. Marka Karpia, Warszawa 2012 (tekst dostępny na stronie : http://www.osw.waw.pl/pl/publikacje/komentarze-osw/2012-0626/prezydencja-cypryjska-a-relacje-turcji-z-unia-europejska).

Aybet G., Muftuler-Bac M., Transformations in Security and Identity after the Cold War: Turkey's Problematic Relationship with Europe, „International Journal" 2000, Vol. 55 No. 2.

Aybet G., Turkey and the EU After the First Year of Negotiations: Reconciling Internal and External Policy Challenges, „Security Dialogue” 2006, Vol. 37, No. 4.

Aybet G., Turkey's Long and Winding Road to the EU: Implications for the Balkans, „Journal of Southern Europe and the Balkans” 2006, Vol. 8, No. 1, s. 72.

Aydin M., Turkish Foreign Policy Framework and Analysis, SAM Paper, Center for Strategic Research 2004.

Aydintaşabaş A., Uniting Cyprus: A Settelment that Needs a Final Pusch, „International Herald Tribune", 3 luty 2004.

Bakoyannis D., Does Europe have a message for the world?, „Annual Lecture of Eastern Europe Center", St. Anthony's College, Oxford 2007.

Barkey H. J., Taspinar 0., Turkey: On Europe's Verge, The Foreign Policy Association, 2006. 
Michał Alagierski - Relacje Turcji z Unią...

Canan F., The Impact of Europeanization on Turkish Foreign Policy: An Analysis of Period Since 1999, Londyn 2009.

Cem I., Turkey's Cyprus Policy, „Northen Cyprus Monthly” 2002.

Diaz T., The Imposition of Governance: Transforming Foreign Policy through EU Enlargement, Copenhagen Peace Research Institute, Kopenhaga 2000.

Eryilmaz B., „Europeanization of Turkish Foreign Policy: Cyprus Case”, referat zaprezentowany na konferencji Global and Regional Governance European Perspectives and Beyond, Uniwersytet Wrocławski, Wrocław 2007.

Gordon P., Turkey on the Brink, „The Washington Quarterly” 2006, Vol. 29, No. 3.

Gülmez S. B., The Cyprus Policy of the CHP: Change Or Continuation, Insight Turkey, „Ancara Center for Turkish Policy Studies” 2007, Vol. 9, No. 1.

Hale W., Turkish Foreign Policy, 1774-2000, Routledge, Londyn 2002.

Jung D., Democratization and Development: New Political Strategies for the Middle East, Nowy Jork 2006.

Kinzer S., Bülent Ecevit, a Political Survivor Who Turned Turkey Toward the West, Is Dead at 81, „The New York Times” 2006.

Kramer H., A Changing Turkey: The Challenge to the Europe and the United States, Waszyngton 2000.

Mallinson W., Cyprus: A Modern History, Londyn 2008.

Mango A., The Turks Today, John Muray Publishers, Londyn 2004.

Martin L. G., M. Soysal, The Future of Turkish Foreign Policy, Cambridge 2002.

Mayall S. V., Turkey: Thwarted Ambition, Institute for National Strategic Studies, Waszyngton 1997.

Öktem K., Angry Nation: Turkey since 1989, Londyn 2011.

Öniş Z., The New Wave of Foreign Policy Activism in Turkey: Drifting Away from Europeanization?, DIIS Report 05. Copenhagen: Denish Institute for International Studies, Kopenhaga 2009.

Öniş Z., The Political Economy of Islam and Democracy in Turkey: From the Welfare Party to the AKP, [w:] D. Jung (red.), Democratization and Development: New Political Strategies for the Middle East, Palgrave Macmillan, New York 2006.

Oymen 0., Turkey's European Foreign Policy, Perceptions, „Journal of International Affairs" 1997, Vol. 2. 
Pope H., The EU - Turkey - Cyprus Triangle: Setting the Stage, [w:] „International Crisis Group, Solving the EU - Turkey - Cyprus Triangle", Istanbul/Brussels 2009.

Robins P., Between the EU and the Middle East: Turkish Foreign Policy under the AKP Government, 2002-2007, Mediolan 2007.

Saatçioğlu B., Turkey's Accession to the European Union. Political and Economic Challenges, Plymouth 2013.

Saatçioğlu B., Turkey-EU Relations from the 1960s to 2012, in Turkey's Accession to the European Union. Political and Economic Challenges, Plymouth 2013.

Schimmelfennig F., U. Sedelmeier, The Politics of European Union Enlargement: Theoretical Approaches, Nowy Jork 2005.

Şimşir B., AB, AKP ve Kıbrıs, Bilgi Yajınevi, Ankara 2003.

Soysal M., The Future of Turkish Foreign Policy, [w:] L. G. Martin, M. Soysal (red.), The Future of Turkish Foreign Policy, MA: MIT Press, Cambridge 2002.

Tocci N., Anchoring Turkey to the European Union: The Domestic and Foreign Policy Challenges Ahead, European University Institute, Florencja 2004.

Ulusoy K., Europeanization Time Constraint: The Cyprus Case, [w:] B. Akçay, B. Yilmaz (red.), Turkey's Accession to the European Union: political and Economic Challenges, Lexington Books, Nowy Jork 2013, s. 281.

Varvick J., Lang K.-O. (red.), European Neighbourhood Policy: Challenges for the EU-Policy Toward the New Neighbours, Barbara Budrich Publishers, Farmington Hills 2007.

Yavuz H., The Emergence of a New Turkey: Democracy and the AKP Party, Salt Lake City 2006.

Yilmaz B., Turkey's Accession to the European Union: political and Economic Challenges, Nowy Jork 2013. 